\title{
Faktor-faktor yang Mempengaruhi Keterlambatan Pasien Stroke Akut Datang ke Lima Rumah Sakit Pemerintah di DKI Jakarta
}

\author{
Edi Prasetyo \\ Neurologi Fakultas Kedokteran Universitas YARSI, Jakarta \\ Correspondence: Email: edi.prasetyo@yarsi.ac.id
}

\begin{abstract}
Abstrak
Bahaya penyakit stroke umumnya belum disadari secara luas oleh masyarakat sehingga mengakibatkan kecacatan dan kematian cukup tinggi baik di Indonesia. Disain penelitian potong lintang dengan responden pasien stroke (iskemik maupun hemoragik), serangan pertama maupun berulang yang datang ke lima rumah sakit pemerintah di lima wilayah di DKI Jakarta. Sebanyak 110 subyek digunakan dalam penelitian dan faktor-faktor yang diamati adalah sebaran waktu kedatangan, usia, jenis kelamin, pendidikan, suku, pengetahuan tentang stroke, gejala klinis, jarak tempat tinggal dengan rumah sakit, tingkat pendapatan, pembiayaan. Karakteristik penderita stroke di rumah sakit pemerintah di lima wilayah DKI Jakarta mayoritas usia produktif, laki-laki, tingkat pendidikan rendah, berpendapatan rendah, umumnya berasal dari suku jawa dan lamanya waktu kedatangan ke rumah sakit lebih dari tiga jam. Faktor yang mempercepat kedatangan adalah jarak antara rumah pasien ke rumah sakit.
\end{abstract}

Kata Kunci : stroke, jenis kelamin, usia, suku Jawa

\begin{abstract}
The danger of stroke is generally not widely recognized by the community that results in high disability and death both in Indonesia. This study design is a cross sectional, the respondents are ischemic and hemorrhagic strokes, first and recurrent attacks that came to five government hospitals in five regions of Jakarta DKI province. This study takes 110 stroke subjects and the factors are arrival time, age, gender, education, ethnicity, knowledge of stroke, clinical symptoms, distance of residence with hospital, income level, and financing. Characteristics of stroke patients at five government hospitals in five regions of Jakarta DKI province are the majority of productive age, men, low education level, low income, generally from Javanese tribes and the length of time to hospital is more than three hours. The factor that speeds up arrival of patient is the distance between the patient's house and the hospital.
\end{abstract}




\section{Pendahuluan}

Stroke menurut WHO didefinisikan sebagai suatu keadaan klinis atau sindroma yang terjadi secara mendadak atau berkembang sangat cepat akibat gangguan fungsi otak fokal atau global dengan kelainan yang menetap selama 24 jam atau lebih serta mempunyai kecenderungan memburuk bahkan menyebabkan kematian tanpa adanya penyebab lain selain faktor vascular (WHO, 1978). Meskipun semakin berkembangnya pengetahuan mengenai terapi stroke yang efektif, namun hal tersebut mengalami kesulitan dalam mengaplikasikannya pada pasien, hal ini terutama diakibatkan oleh lamanya pasien stroke dalam mencari pertolongan medis. Di Amerika sekitar 700.000 pasien mengalami kejadian stroke pertahunnya, 167.000 di antaranya mengalami kematian, sedangkan sisanya akan mengalami kecacadan dengan berbagai derajat. Dari jumlah kematian tersebut, hampir setengahnya terjadi sebelum pasien mencapai rumah sakit (RS) (Moser et al., 2006). Banyak kematian dan kecacatan dapat dicegah apabila pasien datang ke rumah sakit lebih awal.Efektifitas terapi stroke akut sangat bergantung pada waktu dimulainya terapi setelah onset gejala stroke (Baron et al., 1995; Wester et al., 1999; Rasyid et al., 2007). Keluaran pasien pasca perawatan tidak hanya ditentukan oleh ketepatan dalam tatalaksana stroke, namun juga pengenalan awal gejala stroke dan cepatnya penderita tiba di rumah sakit. Studi klinik menunjukkan bahwa iskemia serebral yang dibiarkan menetap dan tidak ditangani lebih dari enam jam menyebabkan keluaran yang lebih buruk pada pasien stroke iskemik akut dibandingkan yang datang segera mencari pertolongan. Bahaya penyakit stroke belum disadari secara luas oleh masyarakat sehingga pasien stroke seringkali lambat datang ke rumah sakit untuk mendapatkan penanganan medis. Umumnya masyarakat baru akan mencari pertolongan apabila terdapat gejala klinis dan gangguan fungsi yang berat, sedangkan gejala yang ringan kurang mendapatkan respon padahal gejala yang ringan ini juga dapat mengakibatkan kecacadan dan kematian bila tidak diatasi segera. Penanganan yang optimal pada jam-jam awal terjadinya stroke akan menurunkan angka kecacatan sebesar 30\% (Jorgensen et al., 1996).

Di Eropa, Copenhagen Stroke Study menguraikan bahwa penyebab lamanya kedatangan pasien stroke tiba di rumah sakit (RS) diantaranya karena faktor demografi, geografi, serta faktor medis. Faktor-faktor tersebut menyebabkan pasien tiba di rumah sakit lebih dari 6 jam. $^{7}$ Di Asia, Lau et al. melakukan penelitian pada tahun 2003 di Accident and Emergency Department of Princess Margaret Hospital (PMH), Hong Kong. Seratus lima belas pasien yang diikutsertakan dalam penelitian dibagi menjadi 2 kelompok, yakni mereka yang datang dengan ambulans 999 dan yang tidak. Pada kelompok yang datang tanpa ambulans median waktu tiba di RS adalah 950 menit (1 hari 5 jam 50 menit), sedangkan pada mereka yang datang dengan ambulans waktu kedatangan lebih singkat. Mereka dibagi ke dalam 3 fase yakni fase I (onset hingga menelpon 999) dengan median 151 menit (2 jam 31 menit), fase II (menelpon 999 hingga datang ambulans) dengan median 32 menit, dan fase III (ambulans hingga ke RS) dengan median 17 menit. ${ }^{8}$ Penelitian lainnya dilakukan oleh Chang et al. tahun 2004 di Taiwan menyebutkan bahwa median time antara onset gejala dan keputusan untuk mencari pertolongan medis adalah 90 menit, sedangkan median time antara onset 
gejala dan kedatangan di RS adalah 335 menit (Barber et al., 2001' Chang et al., 2004). Menurut Kelly, sejak tahun 1981 setidaknya terdapat 48 laporan penelitian. Mayoritas studi melaporkan median time dari mulai timbulnya gejala sampai pasien tiba di rumah sakit sekitar 3-6 jam (Bohannon et al., 2003). Beberapa penelitian serupa juga pernah dilakukan namun sifatnya terbatas dan hasilnya pun masih kontradiktif antar penelitian (Jarell et al., 2007). Hal ini mungkin diakibatkan oleh perbedaan desain penelitian, dan kebanyakan penelitian hanya mengeksporasi variabel dalam jumlah terbatas. Penelitian pun terbatas dilakukan di luar negeri dan belum ada penelitian sejenis di Indonesia.

\section{Bahan dan Metoda Penelitian}

Desain penelitian potong lintang, dilakukan di lima RS pemerintah di DKI Jakarta, yaitu: RSUPN Cipto Mangukusumo (RSCM), Rumah Sakit Umum Pusat Fatmawati (RSF), Rumah Sakit Umum Daerah Pasar Rebo (RSPR), Rumah Sakit Umum Daerah Koja (RS Koja), Rumah Sakit Umum Daerah Tarakan (RS Tarakan). Metode pemilihan sampel yang digunakan adalah non-random sampling jenis konsekutif. Sampel sebanyak 110 pasien stroke akut yang didampingi keluarga dan bersedia menjadi responden.

\section{Hasil Penelitian}

Sebanyak 110 subyek berasal dari 43 orang dari RS Fatmawati, 36 orang dari RS Cipto Mangunkusumo, 19 orang dari RS Koja, 8 orang dari RS Pasar Rebo, dan 4 orang dari RS Tarakan. Pada penelitian ini terlihat ketidakseimbangan dari jumlah subyek yang diambil dari kelima RS penelitian, selain dikarenakan pemilihan sampel non-random sampling jenis konsekutif, juga karena di RS
Tarakan saat dilakukan pengambilan sampel $C T$ scan sempat rusak dan banyak di antara keluarga pasien yang tidak ada sehingga tidak masuk ke dalam kriteria inklusi. Di RS Pasar Rebo ruang rawat neurologi digabung dengan ruang rawat penyakit dalam, sehingga jumlah pasien neurologi, khususnya stroke, yang ada juga sedikit. Dari hasil pemeriksaan CT-scan kepala sebesar $65.5 \%$ subyek mengalami stroke iskemik.

\section{Sebaran Waktu Kedatangan (Likelihood of Behavior Change)}

Sebaran waktu kedatangan (likelihood of behavior change) dapat dilihat pada Tabel 1. Dari 110 subyek, hanya 27 orang (24.5\%) yang datang dengan onset $\leq 3$ jam. Sebagian besar pasien $(75.5 \%)$ subyek datang setelah $>3$ jam onset, dengan presentasi terbanyak yakni onset setelah 1 hari $(41.8 \%)$.

Tabel 1. Sebaran Waktu Kedatangan (Likelihood of Behavior Change)

\begin{tabular}{cccc}
\hline $\begin{array}{c}\text { Waktu Kedatangan di } \\
\text { RS Sejak Onset Stroke }\end{array}$ & \multicolumn{2}{c}{$\mathbf{n}(\%)$} \\
\hline 3 jam & $<1$ jam & 13 & 27 \\
& & $(11.8)$ & $(24.5)$ \\
& $1-3$ jam & 14 & \\
$>3$ jam & $3-6$ jam & $(12.7)$ & \\
& $>6$ jam s/d 1 & 27 & $(75.4)$ \\
& hari & $(24.5)$ & \\
& $>1$ hari & 46 & \\
& & $(41.8)$ & \\
\hline
\end{tabular}

\section{Sebaran Modifying Factors}

Sebaran modifying factors dapat dilihat pada Tabel 2. Berdasarkan usia, subyek yang mengalami stroke terbanyak pada usia 41-64 tahun sebesar $56.4 \%$, disusul usia lanjut $(\geq 65$ tahun) sebesar $37.3 \%$, dan usia muda ( $\leq 40$ tahun) sebesar $6.4 \%$. Berdasarkan jenis kelamin didapat laki-laki (57.3\%) sebagai subyek terbesar. Berdasarkan sebaran pendidikan, 
$51.8 \%$ subyek berpendidikan rendah yakni mereka yang tidak sekolah/tidak mendapat pendidikan formal hingga tamat/tidak tamat SMP atau sederajat. Hanya $15 \%$ subyek berpendidikan tinggi yakni mereka yang tamat/tidak tamat S1 hingga jenjang pendidikan yang lebih lanjut dari S1. Dari $59.1 \%$ subyek yang tidak bekerja, persentase terbesar terdapat pada ibu rumah tangga (39.1\%), subyek yang tidak memiliki pekerjaan (12.7\%), dan pensiunan (7.3\%). Pada subyek yang bekerja, 32.7\% memiliki pekerjaan sebagai swasta dan $8.2 \%$ sebagai pegawai negeri sipil (PNS). Dari seluruh subyek yang masuk ke dalam kriteria inklusi penelitian, suku Jawa dan Sunda memiliki persentase yang sama yakni $29.1 \%$, disusul suku Betawi $26.4 \%$, dan sisanya suku Tapanuli $10 \%$ serta Minang $5.5 \%$.

\section{Sebaran Perceived Susceptibility}

Menggambarkan sebaran perceived susceptibility. Kesepuluh pertanyaan yang diajukan meliputi definisi stroke, faktor risiko, gejala, tindakan, dokter yang dituju, komplikasi, antisipasi, kedaruratan, pencegahan, dan rehabilitasi. Dari Tabel 3. dapat dilihat skor total pengetahuan tentang stroke $58.2 \%$ subyek memiliki pengetahuan yang kurang, hanya $19.1 \%$ subyek yang memiliki pengetahuan baik.

\section{Sebaran Perceived Threat}

Menggambarkan sebaran perceived threat. Dari 110 subyek, sebesar $80.9 \%$ muncul gejala secara mendadak. Sebesar $53.6 \%$ mengalami kesadaran menurun. Dari penelitian juga didapat data bahwa sebesar $74.5 \%$ gejala dikenali bukan oleh pasien sendiri, melainkan oleh orang lain (Tabel 4.).

Tabel 2. Sebaran Modifying Factors

\begin{tabular}{|c|c|c|c|c|}
\hline \multicolumn{3}{|c|}{ Modifying Factors } & \multicolumn{2}{|c|}{ n (\%) } \\
\hline \multirow[t]{5}{*}{ Usia } & $\leq 40$ tahun & $\leq 40$ tahun & $7(6.4)$ & $7(6.4)$ \\
\hline & $\overline{4} 1-64$ tahun & $\overline{4} 1-54$ tahun & $33(30)$ & 62 \\
\hline & & 55-64 tahun & $29(26.4)$ & (56.4) \\
\hline & $\geq 65$ tahun & 65-74 tahun & $28(25.5)$ & 41 \\
\hline & & $\geq 75$ tahun & $13(11.8)$ & (37.3) \\
\hline \multirow[t]{2}{*}{ Jenis Kelamin } & \multicolumn{2}{|l|}{ Laki-laki } & \multicolumn{2}{|c|}{$63(57.3)$} \\
\hline & Perempuan & & \multicolumn{2}{|c|}{$47(42.7)$} \\
\hline \multirow[t]{3}{*}{ Pendidikan } & Rendah & & \multicolumn{2}{|c|}{$57(51.8)$} \\
\hline & Sedang & & \multirow{2}{*}{\multicolumn{2}{|c|}{$\begin{array}{l}38(34.5) \\
15(136)\end{array}$}} \\
\hline & Tinggi & & & \\
\hline \multirow[t]{6}{*}{ Pekerjaan } & PNS & PNS & $9(8.2)$ & $9(8.2)$ \\
\hline & Swasta & Pedagang & $7(6.4)$ & 36 \\
\hline & & Swasta & $29(26.4)$ & (32.7) \\
\hline & Tidak & Pensiunan & $8(7.3)$ & 65 \\
\hline & bekerja & Tidak bekerja & $14(12.7)$ & (59.1) \\
\hline & & $\begin{array}{l}\text { Ibu rumah } \\
\text { tangga }\end{array}$ & $43(39.1)$ & \\
\hline \multirow[t]{5}{*}{ Suku } & Jawa & Jawa & $32(29.1)$ & 64 \\
\hline & & Sunda & $32(29.1)$ & (58.2) \\
\hline & Sumatera & Minang & $6(5.5)$ & 17 \\
\hline & & Tapanuli & $11(10)$ & (15.5) \\
\hline & Betawi & Betawi & $29(26.4)$ & $\begin{array}{c}29 \\
(26.4)\end{array}$ \\
\hline
\end{tabular}


Tabel 3. Sebaran Perceived Susceptibility

\begin{tabular}{lcc}
\hline \multicolumn{2}{c}{ Perceived Susceptibility } & n (\%) \\
\hline Definisi & Benar & $46(41.8)$ \\
Faktor Risiko & Salah & $64(58.2)$ \\
Gejala & Benar & $24(21.8)$ \\
& Salah & $86(78.2)$ \\
Tindakan & Benar & $34(30.9)$ \\
& Salah & $76(69.1)$ \\
Dokter yang Dituju & Benar & $90(81.8)$ \\
& Salah & $20(18.2)$ \\
Komplikasi & Benar & $94(85.5)$ \\
& Salah & $16(14.5)$ \\
Antisipasi & Benar & $35(31.8)$ \\
& Salah & $75(68.2)$ \\
Kedaruratan & Benar & $44(40)$ \\
& Salah & $66(60)$ \\
Pencegahan & Benar & $76(69.1)$ \\
\multirow{2}{*}{ Rehabilitasi } & Salah & $34(30.9)$ \\
& Benar & $61(55.5)$ \\
Pengetahuan & Salah & $49(44.5)$ \\
& Benar & $68(61.8)$ \\
& Salah & $42(38.2)$ \\
& Baik & $21(19.1)$ \\
& Cukup & $25(22.7)$ \\
& Kurang & $64(58.2)$ \\
\hline
\end{tabular}

Tabel 4. Sebaran Perceived Threat

\begin{tabular}{llc}
\hline \multicolumn{2}{c}{ Perceived Threat } & n (\%) \\
\hline Munculnya Gejala & Mendadak & $89(80.9)$ \\
\multirow{2}{*}{ Kesadaran } & Bertahap & $21(19.1)$ \\
\multirow{2}{*}{ Pengenalan Gejala Awal } & Sadar & $51(46.4)$ \\
& Tidak sadar & $59(53.6)$ \\
& Pasien sendiri & $28(25.5)$ \\
& Orang lain & $82(74.5)$ \\
\hline
\end{tabular}

\section{Sebaran Perceived Benefits Minus B arrier}

Sebaran perceived benefits minus barrier dapat dilihat pada Tabel 5. Dari 110 subyek, hanya $36.4 \%$ pasien yang tinggal seorang diri. Berdasarkan jarak, meskipun jarak dari rumah ke Rumah Sakit jauh (> $15 \mathrm{KM}$ ), namun sebesar 47.3\% pasien tetap berobat ke Rumah Sakit tersebut. Tingkat pendapatan sebagian besar subyek rendah (< Rp.1.290.000,-/bulan) yakni sebesar 59.1\%. Dari segi pembiayaan, $70.9 \%$ subyek mendapat pembiayaan dari pemerintah dengan pembagian 20.9\% ASKES/Jamsostek dan $50 \%$ JAMKESMAS/JAMKESDA/GAKIN.
Selebihnya, 26.4\% subyek membayar secara pribadi dan hanya $2.7 \%$ pasien yang mendapat tanggungan dari perusahaan atau asuransi swasta. Sebesar $65.5 \%$ subyek memilih Rumah Sakit penelitian sebagai sarana kesehatan pertama kali dihubungi, $28.2 \%$ memilih pelayanan kesehatan primer, dan $6.4 \%$ menghubungi praktek neurolog. Dari seluruh subyek, hanya $4.5 \%$ subyek yang menggunakan ambulans sebagai sarana transportasi menuju RS. Sebesar $70.9 \%$ pasien menghubungi keluarga yang lain terlebih dahulu sebelum menuju ke RS. 


\section{Sebaran Cues to Action}

Sebaran cues to action dapat dilihat pada tabel. Sebanyak $27.3 \%$ subyek pernah mengalami stroke sebelumnya. Sebagian besar pasien $(66.4 \%)$ dan keluarga $(61.8 \%)$ belum pernah menerima informasi stroke sebelumnya. Pada mereka yang pernah mendapat informasi tentang stroke, umumnya mereka mendapat informasi dari tenaga kesehatan sewaktu mengalami stroke sebelumnya, hanya sebagian kecil yang mendapat informasi dari media (Tabel 6.).

\section{Hubungan Antara Waktu Kedatangan dan Faktor-faktor yang Mempengaruhinya}

Dari banyak faktor yang mempengaruhi waktu kedatangan pasien stroke akut ke Rumah Sakit penelitian, hanya status tinggal, jarak, dan ambulans yang berpengaruh secara bermakna. Hubungan antara waktu kedatangan dan faktorfaktor yang mempengaruhi dapat dilihat pada Tabel 7.

Tabel 5. Sebaran Perceived Benefits Minus Barriers

\begin{tabular}{|c|c|c|c|c|}
\hline \multicolumn{3}{|c|}{ Perceived Benefits Minus Barriers } & \multicolumn{2}{|c|}{ n (\%) } \\
\hline \multirow[t]{2}{*}{ Status Tinggal } & \multicolumn{2}{|c|}{ Sendiri } & \multicolumn{2}{|c|}{$40(36.4)$} \\
\hline & \multicolumn{2}{|c|}{ Bersama orang lain } & \multicolumn{2}{|c|}{$70(63.6)$} \\
\hline \multirow[t]{4}{*}{ Jarak } & Dekat & $0-5 \mathrm{KM}$ & $9(8.2)$ & $9(8.2)$ \\
\hline & Sedang & $6-10 \mathrm{KM}$ & $24(21.8)$ & 49 (44.5) \\
\hline & & $11-15 \mathrm{KM}$ & $25(22.7)$ & \\
\hline & Jauh & $>15 \mathrm{KM}$ & $52(47.3)$ & $52(47.3)$ \\
\hline Tingkat & \multicolumn{2}{|c|}{ Rendah (< Rp.1.290.000,-/bulan) } & \multicolumn{2}{|c|}{$65(59.1)$} \\
\hline \multirow[t]{2}{*}{ Pendapatan } & \multicolumn{2}{|c|}{$\begin{array}{l}\text { Sedang (Rp.1.290.000,- s/d Rp.5.000.000,- } \\
\text { /bulan) }\end{array}$} & \multicolumn{2}{|c|}{$35(31.8)$} \\
\hline & \multicolumn{2}{|c|}{ Tinggi (> Rp.5.000.000,-/bulan) } & \multicolumn{2}{|c|}{$10(9.1)$} \\
\hline \multirow[t]{3}{*}{ Pembiayaan } & Pemerintah & $\begin{array}{l}\text { ASKES/Jamsostek } \\
\text { JAMKESMAS/JAMKESDA/GAKIN }\end{array}$ & \multicolumn{2}{|c|}{$55(50)$} \\
\hline & Swasta & $\begin{array}{l}\text { Asuransi swasta } \\
\text { Perusahaan }\end{array}$ & $\begin{array}{l}2(1.8) \\
1(0.9)\end{array}$ & $3(2.7)$ \\
\hline & \multirow{2}{*}{\multicolumn{2}{|c|}{$\begin{array}{l}\text { Pribadi } \\
\text { RS }\end{array}$}} & $29(26.4)$ & $29(26.4)$ \\
\hline Sarana & & & \multicolumn{2}{|c|}{$72(65.5)$} \\
\hline Kesehatan & \multicolumn{2}{|c|}{ Praktek neurolog } & \multicolumn{2}{|c|}{7 (6.4) } \\
\hline $\begin{array}{l}\text { yang Pertama } \\
\text { Kali Dihubunai }\end{array}$ & \multicolumn{2}{|c|}{ Pelayanan kesehatan primer } & \multicolumn{2}{|c|}{$31(28.2)$} \\
\hline Ambulans & \multicolumn{2}{|l|}{ Ya } & \multicolumn{2}{|c|}{$5(4.5)$} \\
\hline & \multicolumn{2}{|l|}{ Tidak } & \multicolumn{2}{|c|}{$105(95.5)$} \\
\hline Menghubungi & \multicolumn{2}{|l|}{ Ya } & \multicolumn{2}{|c|}{$78(70.9)$} \\
\hline $\begin{array}{l}\text { Keluarga yang } \\
\text { Lain }\end{array}$ & \multicolumn{2}{|l|}{ Tidak } & & $32(29.1)$ \\
\hline
\end{tabular}

Tabel 6. Sebaran Cues to Action

\begin{tabular}{lll}
\hline \multicolumn{1}{c}{ Cues to Action } & & n (\%) \\
\hline Riwayat Stroke & Ya & $30(27.3)$ \\
& Tidak & $80(72.7)$ \\
Informasi Stroke & Ya & $37(33.6)$ \\
Sebelumnya Oleh Pasien & Tidak & $73(66.4)$ \\
Informasi Stroke & Ya & $42(38.2)$ \\
\cline { 2 - 3 } Sebelumnya Oleh Keluarga & Tidak & $68(61.8)$ \\
\hline
\end{tabular}


Tabel 7. Hubungan Antara Waktu Kedatangan dan Faktor-faktor yang Mempengaruhinya

\begin{tabular}{|c|c|c|}
\hline \multicolumn{2}{|c|}{ Faktor-faktor yang Mempengaruhi Waktu Kedatangan } & \multirow{2}{*}{$\frac{\mathbf{p}}{0.60}$} \\
\hline Modyfing factors & Usia & \\
\hline & Jenis kelamin & 0.81 \\
\hline & Pendidikan & 0.11 \\
\hline & Pekerjaan & 0.20 \\
\hline & Suku & 0.91 \\
\hline Perceived susceptibility & Pengetahuan tentang stroke & 0.12 \\
\hline \multirow[t]{3}{*}{ Perceived threat } & Munculnya gejala & 0.52 \\
\hline & Kesadaran & 0.12 \\
\hline & Pengenalan gejala awal & 0.57 \\
\hline \multirow{7}{*}{$\begin{array}{l}\text { Perceived benefits minus } \\
\text { barrier }\end{array}$} & Status tinggal & 0.05 \\
\hline & Jarak & 0.01 \\
\hline & Tingkat pendapatan & 0.88 \\
\hline & Pembiayaan & 0.60 \\
\hline & Sarana kesehatan yang pertama kali dihubungi & 0.53 \\
\hline & Ambulans & 0.05 \\
\hline & Menghubungi keluarga & 0.58 \\
\hline \multirow[t]{3}{*}{ Cues to action } & Riwayat stroke & 0.75 \\
\hline & Informasi stroke pasien & 0.97 \\
\hline & Informasi stroke keluarga & 0.44 \\
\hline
\end{tabular}

\section{Diskusi}

Berdasarkan sebaran waktu, peneliti membagi dalam 5 kategori waktu (Tabel 1) hal ini karena definisi terlambat di indonesia berdasarkan terapi menurut waktu (timedependent therapies) belum dapat dilakukan kerena terbatasnya sarana dan pra sarana, namun berdasarkan kaskade waktu kejadian stroke akut dan terapi-terapi yang terkait dengan waktu (time-dependent therapies) antara lain recombinant tissue plasminogen activator (rtPA) harus dimulai dalam 3 jam onset stroke iskemik akut (Marler et al, 2000) dan recombinant activated factor VII harus dimulai dalam 4 jam onset untuk perdarahan maka hasil penelitian dibagi dalam 2 kategori yaitu kurang sama dengan 3 jam dan lebih dari 3 jam dari hasil penelitian ini didapat data bahwa hanya $24.5 \%$ subyek yang datang tepat atau sebelum 3 jam dari onset stroke, selebihnya (75.4\%) datang setelah melewati waktu 3 jam, bahkan 46 subyek datang setelah lewat 1 hari. Di luar negeripun kejadian yang serupa merupakan masalah bagi pemberian terapi tersebut. Pada penelitian Barber et al. di tahun 2001, dari 1168 pasien stroke iskemik hanya $27 \%$ yang datang sebelum 3 jam onset (1.4\% mendapat terapi rtPA) (Barber et al., 2001). Keterlambatan ini terutama disebabkan oleh keterlambatan datang ke rumah sakit (prehospital delay) dengan beberapa faktor yang mempengaruhinya. Pada penelitian ini dilihat faktor-faktor penyebab keterlambatan pasien stroke datang ke rumah sakit berdasarkan health belief model yang terdiri atas 
modifying factors, perceived susceptibility, perceived threat, perceived benefits minus barriers, dan cues to action.

Perceived threat yang diteliti adalah munculnya gejala stroke, tingkat kesadaran pasien, dan pengenalan gejala awal. Dari 110 subyek, sebesar $80.9 \%$ muncul gejala secara mendadak. Sebesar $53.6 \%$ subyek mengalami kesadaran menurun. Dari penelitian juga didapat data bahwa sebesar $74.5 \%$ gejala dikenali bukan oleh pasien sendiri, melainkan oleh orang lain. Derajat keparahan stroke dikatakan mempengaruhi datangnya pasien ke rumah sakit (Derex et al., 2002), semakin berat gejala semakin cepat pula waktu kedatangan di rumah sakit. Namun, pada penelitian ini tidak didapatkan hubungan yang bermakna antara faktor perceived threat (munculnya gejala stroke, tingkat kesadaran pasien, dan pengenalan gejala awal) dengan waktu kedatangan, sama halnya pada banyak studi yang telah dilakukan (Menon et al., 1998; Smith et al., 1998; Kothari et al., 19999; Zweifler et al.,, 2002). Hal ini mungkin disebabkan adat istiadat di indonesia yang masih menjunjung tinggi sistem kekeluargaan bahwa untuk membawa anggota keluarga yang sakit didasari keputusan dari kepala keluarga atau anggota keluarga yang tertua sehingga apabila yang terserang stroke adalah kepala keluarga walaupun kondisi pasien sudah gawat ini tentu mempengaruhi pengambilan keputusan secara cepat karena masih perlu menunggu persetujuan atau keputusan bersama.

Modyfying factors yang diteliti yakni usia, jenis kelamin, pendidikan, pekerjaan, dan suku. Dari penelitian ini didapatkan hasil bahwa stroke terbanyak dialami pada usia 41-64 tahun sebesar $56.4 \%$, usia lanjut ( $\geq 65$ tahun) sebesar $37.3 \%$, dan usia muda ( $\leq 40$ tahun) sebesar
6.4\%. Dengan demikian stroke yang dialami pada mereka dengan usia produktif sebesar $62.8 \%$. Hal ini patut menjadi perhatian mengingat berdasarkan data Profil Kesehatan Indonesia 2008, komposisi penduduk Indonesia menurut kelompok umur menunjukkan sebesar $67.67 \%$ penduduk berada di usia produktif (1564 tahun) (Depkes RI, 2009). Dengan dialaminya stroke pada usia produktif berarti angka beban tanggungan akan semakin tinggi, khususnya bila stroke dialami oleh mereka yang menjadi tulang punggung keluarga.

Berdasarkan jenis kelamin didapat lakilaki $(57.3 \%)$ sebagai subyek terbesar. Dari 63 subyek laki-laki, $68.3 \%$ berusia produktif. Berdasarkan sebaran pendidikan, $51.8 \%$ subyek berpendidikan rendah yakni mereka yang tidak sekolah/tidak mendapat pendidikan formal hingga tamat/tidak tamat SMP atau sederajat. Hanya $15 \%$ subyek berpendidikan tinggi yakni mereka yang tamat/tidak tamat S1 hingga jenjang pendidikan yang lebih lanjut dari S1. Pengetahuan yang dipengaruhi oleh tingkat pendidikan merupakan salah satu faktor pencetus (predisposing) yang berperan dalam mempengaruhi keputusan seseorang untuk berperilaku sehat (Depkes RI, 2009).

Dari $59.1 \%$ subyek yang tidak bekerja, persentase terbesar terdapat pada ibu rumah tangga $(39.1 \%)$, subyek yang tidak memiliki pekerjaan (12.7\%), dan pensiunan (7.3\%). Pada subyek yang bekerja, $32.7 \%$ memiliki pekerjaan sebagai swasta dan $8.2 \%$ sebagai pegawai negeri sipil (PNS). Data Profil Kesehatan Indonesia 2008 menunjukkan bahwa hanya sebesar $9 \%$ dari angkatan kerja Indonesia yang menjadi pengangguran terbuka (Depkes RI, 2009). Suku Jawa dan Sunda memiliki persentase yang sama yakni $29.1 \%$, disusul suku Betawi $26.4 \%$, dan sisanya suku Tapanuli 
10\% serta Minang 5.5\%. DKI Jakarta merupakan propinsi terpadat di Indonesia, di mana penduduknya terdiri dari berbagai macam suku (Depkes RI, 2009). Dari modifying factors yang diteliti yakni usia, jenis kelamin, pendidikan, pekerjaan, dan suku ternyata tidak satupun yang memiliki hubungan dengan waktu kedatangan. Pada studi lain yang melihat hubungan antara usia dengan waktu kedatangan pasien stroke (Lacy et al., 2001; Kothari et al., 1997; Chang et al., 2004), mengatakan bahwa terdapat hubungan yang bermakna antara keduanya, namun hal ini tidak ditemukan pada penelitian ini sama seperti pada banyak studi lain. Jenis kelamin juga ternyata tidak berhubungan dengan waktu kedatangan, sama seperti halnya pada banyak studi. Dari beberapa penelitian yang mencari hubungan antara tingkat pendidikan dengan waktu kedatangan (Menon et al., 1998; Lin et al., 1999; William et al., 1997), tidak ditemukan adanya hubungan yang bermakna. Beberapa studi mengenai hubungan jenis pekerjaan dengan waktu kedatangan Lacy et al., 2001; Kothari et al., 1997; Menon et al., 1998; Smith et al., 1998) juga tidak menemukan hubungan yang bermakna. Pada penelitian ini juga dilihat apakah suku memiliki pengaruh terhadap waktu kedatangan, mengingat adat dari suku tertentu mempengaruhi cepat atau tidaknya mengambil keputusan (menunggu pendapat keluarga lain) untuk memeriksakan diri ke pusat pelayanan kesehatan. Ternyata pada penelitian ini, suku bukanlah faktor yang mempengaruhi keterlambatan pasien stroke datang ke rumah sakit.

Perceived susceptibility yang diteliti adalah pengetahuan tentang stroke. Pengetahuan akan berkontribusi terhadap perubahan perilaku kesehatan, dalam hal ini pengetahuan pasien mengenai stroke.
Sayangnya, dari kesepuluh pertanyaan yang diajukan, hanya $19.1 \%$ subyek yang memiliki pengetahuan yang baik (skor 8-10), sisanya memiliki pengetahuan yang cukup sebesar $22.7 \%$ (skor 6-7), dan kurang sebesar $58.2 \%$ $($ skor $<6)$. Dari pertanyaan tersebut, sebagian besar subyek mengetahui tindakan yang benar, dokter yang dituju, kedaruratan, pencegahan, dan rehabilitasi penyakit stroke. Namun, mengenai definisi, faktor risiko, gejala, komplikasi, dan antisipasi sebagian besar subyek tidak mengetahuinya. Hal ini perlu menjadi catatan bagi para penyedia pelayanan kesehatan untuk lebih menggalakkan berbagai penyuluhan mengenai stroke, baik berupa kampanye publik maupun program pendidikan, sehingga tingkat kewaspadaan masyarakat akan meningkat sehingga mereka akan merubah perilaku kesehatannya. Namun, dari penelitian ini tidak didapatkan hubungan antara pengetahuan tentang stroke dengan waktu kedatangan pasien, meski banyak studi mengatakan sebaliknya (Chang et al., 2004; Hacke et al., 1995; Yoon et al., 2001) .

Perceived benefits minus barrier yang diteliti adalah status tinggal, jarak, tingkat pendapatan, pembiayaan, sarana kesehatan yang pertama kali dihubungi, ambulans, serta apakah pasien menghubungi keluarga lainnya sebelum datang ke sarana kesehatan. Sebanyak $63.6 \%$ subyek tinggal bersama orang lain dan hanya $36.4 \%$ pasien yang tinggal seorang diri. Masih eratnya hubungan kekeluargaan pada budaya Indonesia kemungkinan besar menyebabkan hal tersebut, sehingga lebih cenderung untuk tinggal bersama orang lain dibanding dengan tinggal seorang diri. Berdasarkan jarak, meskipun jarak dari rumah ke RS jauh (> $15 \mathrm{KM}$ ), namun sebesar $47.3 \%$ pasien tetap berobat ke RS tersebut. Hal ini 
kemungkinan juga berhubungan dengan faktor pembiayaan, karena sebagian besar masyarakat lebih cenderung berobat ke rumah sakit pemerintah dengan alasan biaya yang jauh lebih murah dibanding swasta. Tingkat pendapatan sebagian besar subyek rendah (< Rp.1.290.000,/bulan) yakni sebesar 59.1\%. Kemiskinan menjadi isu yang cukup menyita perhatian berbagai kalangan termasuk kesehatan, karena keterjangkauan masyarakat terhadap pelayanan kesehatan terkait dengan daya beli ekonomi (Depkes RI, 2009). Dari segi pembiayaan, 70.9\% subyek mendapat pembiayaan dari pemerintah dengan pembagian 20.9\% ASKES/Jamsostek dan 50\% JAMKESMAS/ JAMKESDA/GAKIN. Selebihnya, $26.4 \%$ subyek membayar secara pribadi dan hanya $2.7 \%$ pasien yang mendapat tanggungan dari perusahaan atau asuransi swasta. Data Profil Kesehatan Indonesia 2008 menunjukkan bahwa dari penduduk DKI Jakarta, hanya $23.3 \%$ yang mendapat pembiayaan dari asuransi atau perusahaan, yakni sebanyak $14.27 \%$ mendapat pembiayan dari pemerintah berupa ASKES/Jamsostek/JAMKESMAS/ JAMKESDA/GAKIN dan $9.03 \%$ yang mendapat tanggungan dari perusahaan atau asuransi swasta $^{65}$. Pada penelitian ini, studi dilakukan hanya pada lima Rumah Sakit Pemerintah di DKI Jakarta dan tidak mengikut sertakan rumah sakit swasta yang jumlahnya cukup banyak, sehingga gambaran pembiayaan pada penelitian tidak serupa dengan data Profil Kesehatan Indonesia 2008 tersebut. Sebesar $65.5 \%$ subyek memilih Rumah Sakit penelitian sebagai sarana kesehatan pertama kali dihubungi, 28.2\% memilih pelayanan kesehatan primer, dan $6.4 \%$ menghubungi praktek neurolog. Dari data Profil Kesehatan Indonesia 2008 (Depkes RI, 2009), jumlah PUSKESMAS yang ada di DKI Jakarta ada 351 buah, sedangkan rumah sakit sebanyak
124 buah dengan perbandingan pemerintah dan swasta adalah $1: 3$. Dari seluruh subyek, hanya $4.5 \%$ subyek yang menggunakan ambulans sebagai sarana transportasi menuju Rumah Sakit. Sebesar $70.9 \%$ pasien menghubungi keluarga yang lain terlebih dahulu sebelum menuju ke Rumah Sakit. Hal ini kemungkinan berhubungan dengan budaya bangsa Indonesia yang masih mengutamakan kekeluargaan, termasuk untuk memutuskan berobat/tidaknya ke sarana kesehatan.

Di antara perceived benefits minus barrier, ternyata status tinggal, jarak, dan ambulans mempengaruhi waktu kedatangan pasien stroke di Rumah Sakit. Status tempat tinggal mempengaruhi waktu kedatangan pada banyak studi (Rasyid et al., 2007; Bohannon et al., 2004; Derex et al., 2002; Harper et al., 1992; Albers et al., 2000). Dikatakan bahwa pasien yang tinggal seorang diri lebih lama kedatangannya di rumah sakit dua kali lipat ${ }^{5}$. Budaya Indonesia yang sangat kuat sistem kekeluargaannya dengan hidup secara bersama ternyata cukup membantu mempercepat kedatangan pasien stroke. Jarak dari rumah ke Rumah Sakit ternyata memiliki hubungan bermakna dengan waktu kedatangan pada penelitian ini. Terlebih lagi, di DKI Jakarta, faktor jarak juga sangat dipengaruhi oleh faktor kemacetan. Hendaknya hal ini menjadi pertimbangan bagi pemerintah, khususnya di DKI Jakarta, untuk berupaya mencari jalan untuk mengurangi tingkat kemacetan yang ada, sehingga dapat membantu mempercepat pasien stroke datang agar mendapat terapi yang adekuat sehinga angka kecacatan akibat stroke dapat dikurangi. Penggunaan ambulans juga memiliki hubungan bermakna dengan waktu kedatangan pasien stroke pada penelitian ini. Sama halnya pada banyak studi yang 
mengatakan bahwa penggunaan ambulans akan memakan waktu yang lebih singkat dibanding tanpa ambulans (Marler et al., 2000; Salisbury et al., 1998). Namun, sayangnya ambulans masih harus digalakkan lagi oleh pemerintah daerah DKI Jakarta, mengingat pemakaiannya masih sangat terbatas, selain karena kurang sosialisasi juga dari segi sarana dan prasarana yang masih kurang memadai.

Cues to action yang diteliti adalah riwayat stroke, informasi stroke pada pasien, dan informasi stroke pada keluarga yang mendampingi pasien. Riwayat stroke didapatkan pada $27.3 \%$ subyek. Sebagian besar pasien (66.4\%) dan keluarga (61.8\%) belum pernah menerima informasi stroke sebelumnya. Pada mereka yang pernah mendapat informasi tentang stroke, umumnya mereka mendapat informasi dari tenaga kesehatan sewaktu mengalami stroke sebelumnya, hanya sebagian kecil yang mendapat informasi dari media. Hal ini turut menjadi catatan pada pemerintah dan sarana pelayanan kesehatan agar membantu memberikan informasi yang luas kepada masyarakat mengenai penyakit stroke untuk meningkatkan kewaspadaan mereka melalui beragam media komunikasi.

Dari ketiga cues to action, tidak didapatkan hubungan bermakna dengan waktu kedatangan. Melalui studinya, Lacy et al. menunjukkan adanya kontribusi riwayat stroke dengan kewaspadaan dan pengenalan gejala stroke akut, sehingga pasien lebih cepat datang mencari pertolongan medis namun banyak penelitian yang menunjukkan tidak adanya hubungan antara riwayat stroke dengan waktu kedatangan (Rasyid et al., 2007; Lacy et al., 2001; Menon et al., 1998; Lin et al., 19999; Srivastava et al., 2001; William et al., 1997; Zweifler et al., 2002; Fogelholm et al., 1996;
Nedeltchev et al., 2003). Ternyata, riwayat stroke tidak mengubah perilaku kewaspadaan pasien stroke, baik kewaspadaan untuk mencegah berulangnya stroke maupun kewaspadaan untuk segera memeriksakan diri ke sarana kesehatan ketika mengalami stroke berikutnya. Informasi mengenai stroke yang pernah didapat pasien atau keluarga sebelumnya juga ternyata tidak berhubungan dengan lamanya kedatangan pasien stroke di rumah sakit (Lin et al., 19999; Rosamond et al., 1998; William et al., 1997). Hal ini perlu menjadi catatan pula, apakah informasi yang diberikan kepada pasien dan keluarga mengenai stroke sudah benar atau tidak. Perlu diadakan koordinasi lebih lanjut antara pemberi informasi, baik dari sarana pelayanan kesehatan maupun dari media komunikasi lainnya.

Berdasarkan hasil yang didapatkan dari penelitian mengenai waktu kedatangan dan faktor-faktor yang mempengaruhinya, maka hendaknya dikaji lagi berbagai kebijakan yang telah dibuat maupun yang belum dibuat, agar sistem pelayanan kesehatan, khususnya mengenai kedatangan pasien stroke akut, dapat diperbaiki. Dengan adanya perbaikan sistem pelayanan kesehatan diharapkan waktu kedatangan pasien stroke akan lebih cepat sehingga terapi yang diberikan akan lebih efektif dan angka kecacatan dapat dicegah ataupun dikurangi.

\section{Simpulan}

Mayoritas subyek usia produktif, jenis kelamin laki-laki, tingkat pendidikan rendah, tidak bekerja, tingkat pendapatan rendah, dan berasal dari suku di pulau Jawa (Jawa dan Sunda). Dilihat dari waktu kedatangan, sebagian besar subyek datang setelah tiga jam onset stroke, hanya sebagian kecil yang datang tepat atau sebelum tiga jam setelah onset stroke. Status 
tinggal, jarak, dan ambulans mempengaruhi waktu kedatangan pasien stroke.

\section{Daftar Pustaka}

Barber PA, Zhang J, Demchuk AM, Hill MD, Buchan AM. Why are stroke patients excluded from TPA therapy? an analysis of patient eligibility. Neurology 2001;56:1015-20.

Baron JC, von Kummer R, del Zoppo GJ. Treatment of acute ischemic stroke. Stroke 1995;26:2219-21.

Bohannon RW, Silverman IE, Ahlquist M. Time to emergency department arrival and its determinants in patients with acute ischemic stroke. Conn Med 2003;67:1458.

Chang KC, Tseng MC, Tan TY. Prehospital delay after acute stroke in Kaohsiung, Taiwan. Stroke 2004;35:700-4.

Chang KC, Tseng MC, Tan TY. Prehospital delay after acute stroke in Kaohsiung, Taiwan. Stroke 2004;35:700-4.

Departemen Kesehatan Republik Indonesia (Depkes RI). Profil Kesehatan Indonesia 2008. Jakarta, 2009.

Derex L, Adeleine P, Nighoghossian N, Honnorat $J$, Trouillas P. Factors influencing early admission in a French stroke unit. Stroke 2002;33:153-9.

Fogelholm R, Murros K, Rissanen A, Ilmavirta M. Factors delaying hospital admission after acute stroke. Stroke 1996;27:398-400.

Hacke W, Kaste M, Fieschi C, Toni D, Lesaffre $\mathrm{E}$, Kummer RV, et al. Intravenous thrombolysis with recombinant tissue plasminogen activator for acute hemispheric stroke: the European Cooperative Acute Stroke Study (ECASS). JAMA 1995;274:1017-25.
Harper GD, Haigh RA, Potter JF, Castleden CM. Factors delaying hospital admission after stroke in Leicestershire. Stroke 1992;23:835-8.

Jarrell B, Tadros A, Whiteman C, Crocco T, Davis SM. National healthline responses to a stroke scenario; implications for early intervention. Stroke 2007;38:2376-8.

Jorgensen HS, Nakayama H, Reith J, Raaschou $\mathrm{HO}$, Olsen TS. Factors delaying hospital admission in acute stroke: the Copenhagen stroke study. Neurology 1996;47:383-7.

Kothari R, Jauch E, Broderick J, Brott $T$, Sauerbeck L, Khoury J, et al. Acute stroke: delays to presentation and emergency department evaluation. Ann Emerg Med 1999;33:3-8.

Kothari R, Sauerbeck L, Jauch E, Broderick J, Brott T, Khoury J, et al. Patients' awareness of stroke signs, symptoms, and risk factors. Stroke 1997;28:1871-5.

Lacy C, Suh D, Bueno M, Kostis J, for the STROKE Collaborative Study Group. Delay in presentation and evaluation for acute stroke: Stroke Time Registry for Outcomes Knowledge and Epidemiology (STROKE). Stroke 2001;32:63-9.

Lin CS, Tsai J, Woo P, Chang H. Prehospital delay and emergency department management of ischemic stroke patients in Taiwan, R.O.C. Prehosp Emerg Care 1999;3:194-200.

Marler JR, Tilley BC, Lu M, Brott TG, Lyden PC, Grotta JC, et al. Early stroke treatment associated with better outcome: The NINDS rt-PA stroke study. Neurology 2000;55:1649-55. 
Menon SC, Pandey DK, Morgenstern LB. Critical factors determining access to acute stroke care. Neurology 1998;51:427-32.

Moser DK, Kimble LP, Alberts MJ, Alonzo A, Croft JB, Dracup K, et al. Reducing delay in seeking treatment by patients with acute coronary syndrome and stroke; a scientific statement from the American Heart Association Council on Cardiovascular Nursing and Stroke Council. Circulation 2006;114:168-82.

Nedeltchev K, Arnold M, Brekenfeld C, Isenegger J, Remonda L, Schroth G, et al.. Pre- and in-hospital delays from stroke onset to intra-arterial thrombolysis. Stroke 2003;34:1230-4.

Rasyid A, Soertidewi L. Unit stroke manajemen stroke secara komprehensif. Jakarta: Fakultas Kedokteran Universitas Indonesia;2007.

Rosamond WD, Gorton RA, Hinn AR, Hohenhaus SM, Morris DL. Rapid response to stroke symptoms: the Delay in Accessing Stroke Healthcare (DASH) study. Acad Emerg Med 1998;5:45-51.

Salisbury HR, Banks BJ, Footitt, Winner SJ, Reynolds DJM. Delay in presentation of patients with acute stroke to hospital in Oxford. Q J Med 1998;91:635-40.

Smith MA, Doliszny KM, Shahar E, McGovern PG, Arnett DK, Luepker RV. Delayed hospital arrival for acute stroke: the
Minnesota Stroke Survey. Ann Intern Med 1998;129:190-6.

Srivastava AK, Prasad K. A study of factors delaying hospital arrival of patients with acute stroke. Neurol India 2001;49:272-6.

Wester P, Radberg J, Lundgren B, Peltonen M. Factors associated with delayed admission to hospital and in-hospital delays in acute stroke and TIA; a prospective, multicenter study. Stroke 1999;30:40-8.

Williams LS, Bruno A, Rouch D, Marriott DJ. Stroke patients' knowledge of stroke: influence on time to presentation. Stroke 1997;28:912-5.

World Health Organisation. Cerebrovascular Disorders (Offset Publications) 1978.

Yoon SS, Heller RF, Levi C, Wiggers J, Fitzgerald PE. Knowledge of stroke risk factors, warning symptoms, and treatment among an Australian urban population. Stroke 2001;32:1926-30.

Zweifler RM, Mendizabal JE, Cunningham S, Shah AK, Rothrock JF. Hospital presentation after stroke in a community sample: the Mobile Stroke Project. South Med J 2002;95:1263-8. 